\title{
Perspektiver på registerforskning i Norge
}

Intervju med Ping Qin

Dr. Ping Qin er professor ved NSSF, og har tidligere arbeidet ved Center for registerstudier ved Århus universitet i Danmark. I sin forskning har professor Qin fokusert på epidemiologi innen selvmord og psykiatri, og hennes studier er i stor grad basert på data fra store befolkningsregistre. Blant Qins viktigste bidrag til selvmordsforskningen er undersøkelser av hvordan kontekstuelle forhold som sosioøkonomiske, demografiske, familiære og biogenetiske faktorer påvirker risikoen for selvmord i ulike grupper av befolkningen. Hun har vært leder for en rekke prosjekter finansiert av forskningsstiftelser i Danmark, Kina og USA, og hun har skrevet mange innflytelsesrike artikler som er publisert i prestisjetunge tidsskrifter, bl.a. Lancet.
Ping Qins nylig initierte prosjekt har som formål å gjennomføre en rekke longitudinelle populasjonsbaserte epidemiologiske studier om selvmord og villet egenskade, basert på eksisterende norske registre. Den store mengden av persondata som tidligere har blitt registrert i forskjellige nasjonale registre og store databaser, vil gjøre det mulig å hente ut data på individnivå med mange forskjellige variabler for å studere den kontekstuelle påvirkningen på risiko for selvmord. Vi spør Qin om hennes erfaring fra registerforskning om selvmord og selvmordsadferd og om planene framover.

\section{- Hvorfor er registerforskning viktig i relasjon til selvmordsatferd?}

- Selvmordsatferd er komplisert og kan påvirkes av mange faktorer i livet. For bedre å forstå dette problemet og for å lage strategier for effektiv forebygging, er store undersøkelser avgjørende for å få solid fundament og for å finne informative retninger for både intervensjon og ytterligere undersøkelser. Forskning basert på data fra folkeregistrene har uten tvil stor betydning i denne forbindelse av en rekke årsaker. For eksempel er det gjennom registre mulig å oppnå en stor studiebefolkning og dermed øke den statistiske styrken. Dette øker muligheten for å oppnå nøyaktige beregninger og å studere eksponering for sjeldne hendelser. Data utledet fra rutinemessige registre er generelt oppsamlet systematisk og jevnt, uavhengig av formålet med spesifikke forskningsprosjekter, noe som kan redusere risikoen for skjevhet grunnet feilklassifikasjon. Dessuten er det gjennom de veletablerte registrene mulig å få nøyaktige inntekt, eksakte datoer for kontakt med sykehus eller leger, etc. - informasjon som generelt er vanskelig å skaffe gjennom intervju eller spørreundersøkelse.

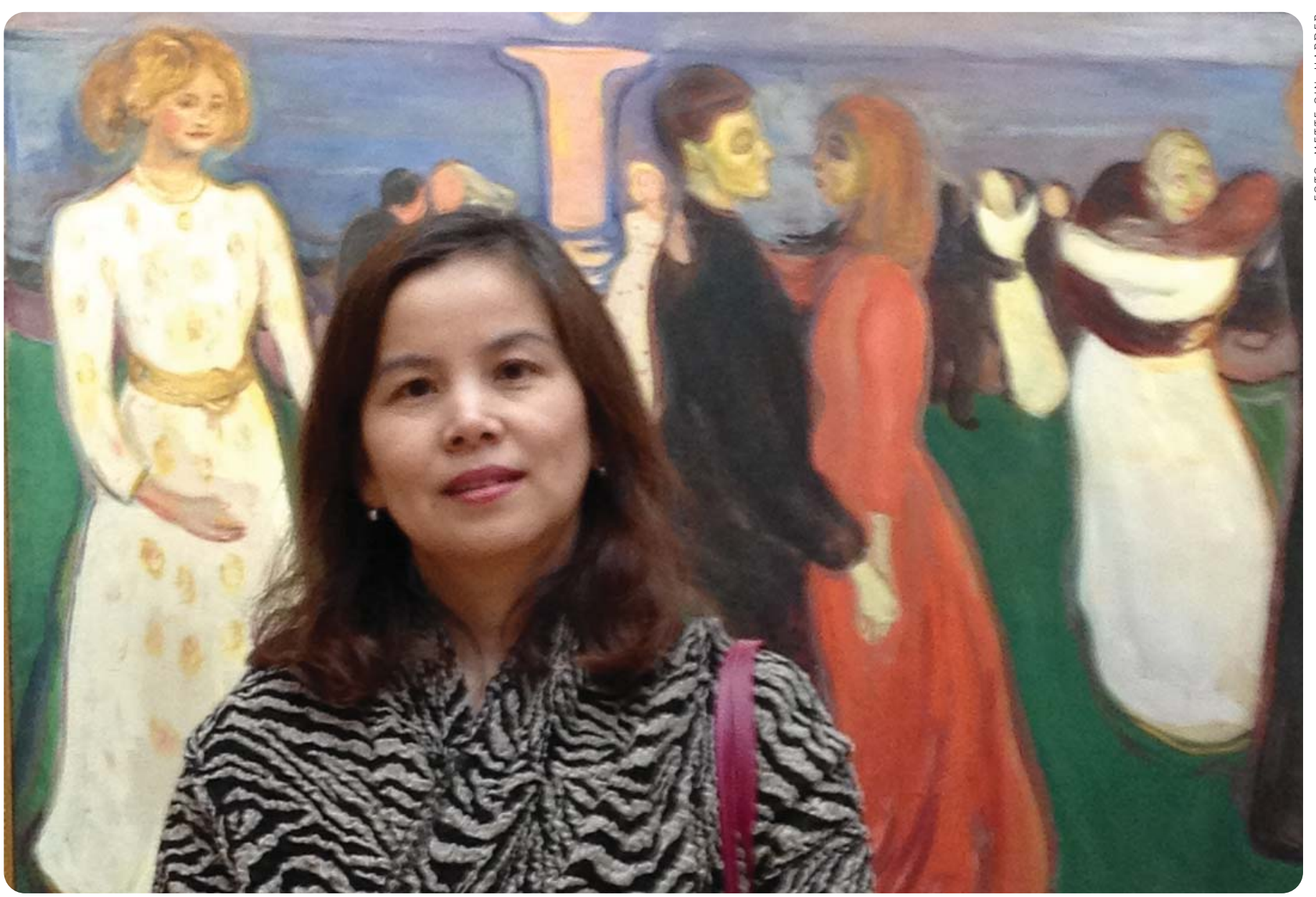




\section{- Hvilke forutsetninger er det for slik forskning i Norge?}

- I likhet med de skandinaviske nabolandene har Norge et velfungerende registreringssystem som har registrert personlig informasjon om mange forhold. Vi har flere registre som inneholder personlige data, automatisk innhentet så langt tilbake som til 1960-tallet, for eksempel Folkeregisteret, Dødsårsaksregisteret og Medisinsk Fødselsregister. Vi har også en rekke registre med kortere dekningsperiode, eksempelvis Norsk Pasientregister og registre på forløpsdata på individers sosioøkonomiske forhold. Data fra disse registrene dekker hele befolkningen i Norge, og kan kobles sammen ved hjelp av det unike fødselsnummeret. Dataområdene dekker fra personlig demografisk status og midlertidig sosioøkonomiske situasjon til kontakter med diverse offentlige myndigheter og helsevesen. Mangfoldigheten i dataene på disse registrene gir godt forskningspotensial både for samfunnsfag og medisinske fag, samt for å studere suicidal atferd.

- Hvilke problemstillinger vil du undersøke?

- Så vidt jeg vet, er det bare noen få publiserte studier om selvmordsatferd som har basert seg på data fra en stor befolk- ning i Norge. Registerbaserte studier er spesielt begrenset. Dette etterlater en rekke interessante og viktig problemstillinger som jeg ønsker å undersøke med data fra eksisterende norske registre. Bare for å nevne noen eksempler, vil jeg gjerne undersøke kvaliteten av registrering på villet egenskade i Norsk Pasientregister, da dette er grunnleggende både for rapportering av suicidal atferd i landet og for bruk av registerdata til å studere suicidal atferd. Jeg ønsker også å gjennomføre ytterligere undersøkelser på emner som selvmordsrisiko i forhold til komorbiditet av fysiske og psykiske sykdommer, sosioøkonomiske ulikheter, belastninger tidlig i livet, betydningen av helsetjenester og så videre. Gjennom kobling av data fra ulike nasjonale registre og store kohort-databaser, er jeg sikker på at vi kan gjennomføre mange høykvalitetsstudier og innhente verdifull kunnskap om suicidalitet.

\section{- Hvilke erfaringer har du med denne typen forskning fra tidligere?}

- Før jeg kom til Nasjonalt Senter for selvmordsforskning og -forebygging, hadde jeg 15 års erfaring med bruk av data fra ulike danske registre for selvmord og psykiatrisk forskning. Slik erfaring beriket ikke bare min kompetanse i å gjennomføre storskala populasjonsbaserte epidemiologiske studier, men har også inspirert meg til å tenke på hvordan kan man maksimere nytten av tilgjengelige datakilder for å belyse de mekanismer og assosierte faktorer av sykdom som undersøkes. Viktigst har jeg gjennom omfattende forskning fått en profesjonell holdning til registerbasert forskning, med hensyn til streng overholdelse av aktuell lovgivning om bruk av personopplysninger for forskning, ivaretakelse av konfidensialiteten for personlige opplysninger hentet fra registre, samt forsiktig fortolkning av forskningsresultater, både på befolknings- og individnivå.

- Er det noen metodiske svakheter eller utfordringer med denne typen forskning?

- Ja, selvfølgelig. Det er noen begrensninger ved bruk av data fra rutinemessige registre til forskningsprosjekter. For eksempel kan perioden for opplysningenes tilgjengelighet være for kort til å oppdage en potensiell sammenheng eller for vurdering av en langsiktig effekt, datakvalitet i enkelte faktorer kan være utilstrekkelige for å gi riktig forståelse og noen ønskelige variabler kan mangle. Disse ufullkommenhetene må behandles grundig ved studiedesign og datakonstruksjon for å minimere mulige skjevheter og for å sikre kvaliteten på studiene.

Selvmord etter kjønn og årstall. 1969-2011. Antall

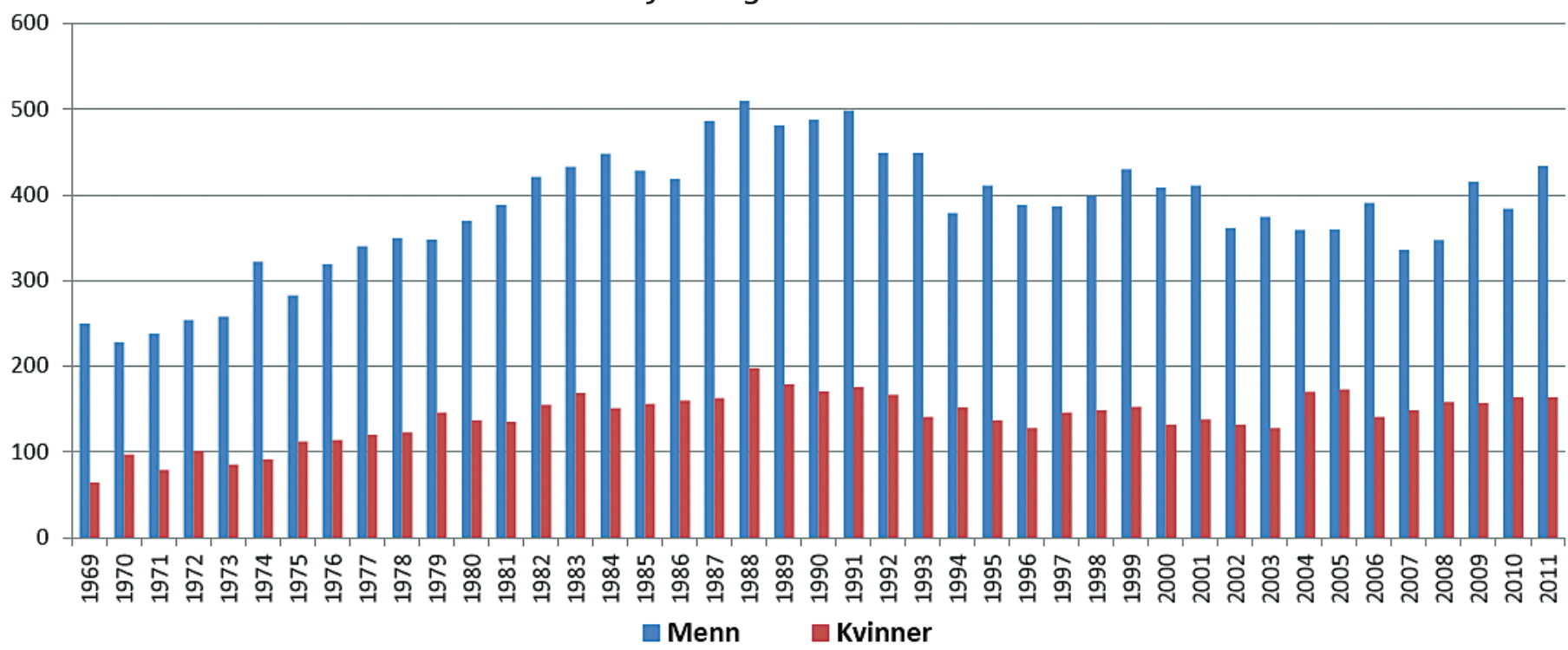

13.12.12 Kilde: ssb.no 